\title{
Comparative Analysis of the proximate Composition of palmyrah pinattu and flours (Odiyal, Boiledodiyal)
}

\author{
S. Srishankar ${ }^{1}$, M. Subajini ${ }^{2}$, W.A.J.P. Wijesinghe ${ }^{3}$, S.M.I.P.G. Bandara ${ }^{4}$, \\ S. SriVijeindran ${ }^{5}$ \\ ${ }^{1,3,4}$ UvaWellassa University, Sri Lanka \\ ${ }^{2,5}$ Palmyrah Research Institute, Jaffna, Sri Lanka
}

\begin{abstract}
Palmyrah (Borassusflabellifer) fruit is mostly used as fresh fruit, because of its perishable nature it is traditionally preserved as dried fruit pulp called as pinattu (fruit leather). It contained pectin as well as contain appreciable amount of saponinbecause of that fruit pulp having important medicinal properties. Considering these facts the phytochemical constituents of solvent extracts of pinattuwas identified and evaluated. Samples was collected from the three different branches ofPalmyrah Development Board.
\end{abstract}

Pinattu, boiled odiyal flour and odiyal flour contained $16.6 \pm(0.008), 11.66 \pm(0.001), 10.66 \pm 0.001 \mathrm{~g} / 100 \mathrm{~g}$ of moisture, $2.23 \pm 0.062,6.51 \pm 0.062,6.7813 \pm 0.06 \mathrm{~g} / 100 \mathrm{~g}$ of protein, $0.08 \pm 0.001,0.28 \pm 0.008,0.43 \pm 0.013 \mathrm{~g} / 100 \mathrm{~g}$ of Fat, $0.04 \pm 0.001$, $0.02 \pm 0.0003,0.02 \pm 0.0002 \mathrm{~g} / 100 \mathrm{~g}$ of Ash, 5.06 $\pm 0.01,7.13 \pm 0.18,4.49 \pm 0.15 \mathrm{~g} / 100 \mathrm{~g}$ of crude fiber and $(75.91 \pm 0.61$, $74.37 \pm 0.65,77.59 \pm 0.5 \mathrm{~g} / 100 \mathrm{~g}$ of carbohydrate respectively. There were significant different $(p<0.05)$ between the each samples for all the nutrient content except moisture content.

Keywords—Pinattu, Odiyalflour, Boiled odiyal flour, Nutritional.

\section{INTRODUCTION}

BorassusflabelliferL., belongs to family Arecaceae,(Asmussenet al., 2006) commonly known as Palmyra palm or Asian toddy palm is a native of tropical Africa (Nesbitt, 2005). The coconut like fruits are three sided when young, becoming rounded or more or less oval, $12-15 \mathrm{~cm}$ wide, and capped at the base with overlapping sepals (Morton, 1988).This plant has a commercial and medicinal value (Ghosh et al., 2012). The fruit pulp of B. flabelliferhas been used in traditional dishes The different parts of the plant is used for the various ailments like secondary syphilis, antiperiodic, heart burns, liver and spleen enlargement etc. It has anti-inflammatory effects (Nadkarni, 1954; Vaidyaratnam, 1994; Kapoor, 2000).

The availability of good data provides a strong foundation for the more important next step - the analysis of the information. So Proximate Nutritional Composition Determination of pinattu, Boiledodiyal flour and odiyal flour also in the analysis of information and facilitate a better understanding of palmyrah products. Measurement of nutritional status is one of the key indicators for monitoring the overall welfare of a population and measuring the impact of change in factors that affect the welfare of a population. Negative change in the nutritional status of a population indicates a problem. (Food Security Analysis Unit for Somalia (FSAU). 2005) and nutrition is the science of food in relation to health. Nowadays the focus on nutrition is based on a new definition of health as "prevention of disease" in which nutrition plays a key role yet most people are unsure whether certain foods are good or bad for them so the Nutritional analysis was most important for the population. Dried raw tuber flour ( odiyal Flour) Raw tubers are split into two halves. Usually they are stored in the form of dried pieces and milled only when needed for make odiyal flour. Boiled odiyal flour Boiled tubers are split into two halves and sun dried then milled into flour is known as Boiled odiyal flour ('Pullukodiyal flour').

\section{MATERIAL AND METHOD}

\subsection{Sampling}

Palmyrah samples were obtained from the three different branches of PDB (Palmyrah Development Board) then pool together. After that $100 \mathrm{~g}$ of sample was weighted in random manner.

\subsection{Proximate analysis}

The proximate compositions of the pinattu, boiledodiyal flour, odiyal flour were determined using standard analytical methods. All measurements were done in duplicates and values presented in percentage. 


\subsection{Determination of Ash content (AOAC 2000)}

\section{Sample preparation}

Sample was prepared and $5 \mathrm{~g}$ of sample was weighed in porcelain crucible. It was kept in muffle furnace at $550^{\circ} \mathrm{C}$ for 5 hours. Then it was transferred in to desiccator for the cooling. The sample was weighed after cooling.

\subsection{Determination of Moisture Content (AOAC 2004)}

Dried petri dishes were taken and weighed $\left(\mathrm{M}_{0}\right)$ by using the analytical balance. Then $5 \mathrm{~g}$ of sample from each were weighed in petri dishes $\left(\mathrm{M}_{1}\right)$. Samples with Petri dishes were placed in the hot air oven at $105^{\circ} \mathrm{c}$ for 3hours. After that dishes were taken and were transferred in to the desiccator and weighed $\left(\mathrm{M}_{2}\right)$. This procedure was repeated until get the constant weight. Then moisture contend was determined.

\subsection{Determination of Protein Content (AOAC 2000)}

$1 \mathrm{~g}$ of samples from each were taken and transferred in to kjeldhal digestion flask carefully. $1 \mathrm{~g}$ of catalyst mixture and $10 \mathrm{ml}$ of con. $\mathrm{H}_{2} \mathrm{SO}_{4}$ was added in to each kjeldhal flask. Then flasks were placed kjeldhal digester at $250^{\circ} \mathrm{C}$ for 90 minutes and then $410^{\circ} \mathrm{C}$ for 90 minutes. After completion of digestion flask were allowed to cool to room temperature. $50 \mathrm{ml}$ of distilled water was added in to each digestion flask. Contents were distilled with addition of $40 \%$ of $\mathrm{NaOH}$. Distillate was collected in conical flask containing $4 \%$ of $15 \mathrm{ml}$ boric acid with mixed indicator. Contents in conical flask were titrated against $0.05 \mathrm{~N}$ $\mathrm{HCl}$ until colour changes from pink to blue.

\section{Protein percentage $=$ Percentage of Nitrogen $\times 6.25$}

\subsection{Fat content determination}

Fat was determined using soxhlet fat extraction method [AOAC 1995].

Sample (5.0g) with filter paper was transferred into pre-weighed thimble and pre-weighed syntax crucible and thimble was attached to the extractor. Fat was extracted with petroleum ether (Boling point $40-60^{\circ} \mathrm{C}, 70 \mathrm{~mL}$ ) in solvent extractor.

Programmed was set as Heating plate temperature $\left(110^{\circ} \mathrm{C}\right)$, Immersion $(60 \mathrm{~min})$, Washing $(60 \mathrm{~min})$, Recovery $(5 \mathrm{~min})$. The concentrated extract with few milliliters of petroleum ether was transferred into clean dried weighed crucible and placed in an oven at $100^{\circ} \mathrm{C}$ for about 30 minutes and it was cooled and weighed. Residual was kept for crude fiber determination.

\subsection{Estimation of Crude fiber}

Crude fiber was determined by Weende method as described in U.S AOAC (1995)

\section{Method}

Fat free sample (1g) was in a pre-weighed Crucible.1.25\% (w/v) of $\mathrm{H}_{2} \mathrm{SO}_{4}$ was adds up to the $150 \mathrm{ml}$ notch after pre heating by the hotplate in order to reduce the time required for boiling. 5 drops of $n$-octanol was added as antifoaming agent, it was boiled for 30 minutes exactly from the onset of boiling, after that connected to vacuum for draining $\mathrm{H}_{2} \mathrm{SO}_{4}$ and washed three times with $30 \mathrm{~mL}$ (crucible filled up to top) of hot demonized water, connecting each time to compressed air for stirring the content of crucible. After draining the last wash $150 \mathrm{~mL}$ of preheated $\mathrm{KOH}(1.25 \% \mathrm{w} / \mathrm{v}))$ was added and 5 drops of antifoam also. Then it was boiled 30 minutes, filtered and washed, last washing with cold deionized water to cool, the crucible and then crucible content was washed three times with $25 \mathrm{ml}$ of acetone, stirring each time by compressed air. Finally the crucible was removed and the dry weight was determined after drying in an oven at $105^{\circ} \mathrm{C}$ for an hour or up to constant weight then cooled in desiccators. This weight represents the crude fiber + ash content in comparison to initial weight. The crucible with insoluble matter was placed in a muffle at $550^{\circ} \mathrm{C}$ for three hours and reweighed after cooling in desiccators. The crude fiber contents in $100 \mathrm{~g}$ sample were calculated. Three replicates were done.

Calculation

$\mathrm{W}_{1} \mathrm{~g} \quad=$ Weight of crucible, Fiber and ash

$\mathrm{W}_{2} \mathrm{~g} \quad=$ Weight of crucible and ash

$\mathrm{W}_{3} \mathrm{~g} \quad=$ Weight of fresh sample

Fiber $\%=\left(\mathrm{W}_{1}-\mathrm{W}_{2}\right) / \mathrm{W}_{3} \times 100$ 


\subsection{Carbohydrate determination}

The carbohydrate content of the test sample was determined by estimation using the arithmetic difference method [D.A.

Pearson 1976].

$$
\% \mathrm{CHO}=100-(\% \text { fat. }+\% \text { ash }+\% \text { fiber }+\% \text { protein })
$$

\subsection{Statistical analysis}

The results obtained from products with three replicate were subjected to analysis of variance by complete randomized design (CRD). The significant difference among the extracts was tested in Least Significant Difference (LSD) at $5 \%$ level of significance using SAS software.

\section{RESULTS AND DISSECTION}

Measurement of nutritional status is one of the key indicators for monitoring the overall health of inhabitants and measuring the impact of change in factors that affect the safety of population. Pinattu, boiled odiyal flour and odiyal flour were showed significant different $(\mathrm{p}<0.05)$ for all nutritional parameters except moisture content. Pinattu showed highest moisture content than flours while there were no significant different between odiyal and boiled odiyal flours. Odiyal flour has highest protein, fat and carbohydrate content when compared with boiled odiyal flour because during the processing of boiled odiyal flour water soluble compound was washed out. Whereas ash and crude fiber content of boiled odiyal flour was significantly higher than odiyal flour. Crude fiber content of pinattu, boiled odiyal flour and odiyal flour were 5.0612( \pm 0.01$), 7.1338( \pm 0.18)$ and $4.4965( \pm 0.15)$ respectively.

\section{TABLE 1}

Proximate COMPOSITION OF PINATTU, BoIledodiYAl FlOUR AND ODIYAL FloUR (g/100g)

\begin{tabular}{|c|c|c|c|}
\hline sample & Pinattu & Boiled odiyal flour & Odiyal flour \\
\hline Moisture & $16.6667( \pm 0.008)^{\mathrm{a}}$ & $11.6667( \pm 0.001)^{\mathrm{b}}$ & $10.6667( \pm 0.001)^{\mathrm{b}}$ \\
\hline Protein & $2.23127( \pm 0.062)^{\mathrm{c}}$ & $6.5188( \pm 0.062)^{\mathrm{b}}$ & $6.7813( \pm 0.062)^{\mathrm{a}}$ \\
\hline Fat & $0.0810( \pm 0.001)^{\mathrm{c}}$ & $0.2840( \pm 0.008)^{\mathrm{b}}$ & $0.4349( \pm 0.013)^{\mathrm{a}}$ \\
\hline Ash & $0.0428( \pm 0.001)^{\mathrm{a}}$ & $0.0213( \pm 0.0003)^{\mathrm{c}}$ & $0.0203( \pm 0.0002)^{\mathrm{b}}$ \\
\hline Crude Fiber & $5.0612( \pm 0.01)^{\mathrm{b}}$ & $7.1338( \pm 0.18)^{\mathrm{a}}$ & $4.4965( \pm 0.15)^{\mathrm{c}}$ \\
\hline Carbohydrate & $75.9171( \pm 0.61)^{\mathrm{b}}$ & $74.3765( \pm 0.65)^{\mathrm{c}}$ & $77.5994( \pm 0.52)^{\mathrm{a}}$ \\
\hline
\end{tabular}

Each value in the table is represented as mean $\pm S D(n=3)$. Values in the same rows followed by a different letter (a-c) are significantly different $(p<0.05)$.

Sahniet al., 2014 stated that the nutritional analysis of the palmyrah dried roots has shown $8.54 \%$ protein content, $23.53 \%$ carbohydrates, $7.29 \%$ crude fiber and negligible fat content.

\section{CONCLUSION}

Findings from this research work have revealed great potential food uses of palmyrah based products. These products have appropriate amount of protein content as well as those were very good source of fiber therefore which could be used in various food applications.

\section{RECOMMENDATIONS}

It is hereby recommended, based on the findings of this research work that increased efforts would be made to encourage the utilization of palmyrah based food products and further studies need to evaluate the antioxidant activity of these palmyrah based products.

Conclusion section must be included and should indicate clearly the advantages, limitations, and possible applications of the paper. Although a conclusion may review the main points of the paper, do not replicate the abstract as the conclusion. A conclusion might elaborate on the importance of the work or suggest applications and extensions. 


\section{ACKNOWLEDGEMENTS}

An acknowledgement section may be presented after the conclusion, if desired.

\section{REFERENCES}

[1] AOAC. 2000. Official methods of analysis. (n.d.) Association of Analytical Chemists, 15th edition Virgina U.S.A 125139.

[2] AOAC.1995. Official Methods of Analysis of the Association of Official Analytical Chemists, 16th ed., Arlington, Virginia: AOAC International

[3] Ahmed Ali1, DjibrillaAlhadji, ClergéTchiegang, Clément Saïdou., 2010 Physicochemical properties of palmyra palm (Borassusaethiopum Mart.) fruits from NorthernCameroonAfrican Journal of Food Science Vol. 4(3), pp. 115-119

[4] Ariyasena DD, Jansz ER, Jayesekera S, Abeysekara AM.Inhibitory effect of bitter principle of palmyra (Borassusflabellifer L.) fruit pulp on the growth of mice: evidenceusing bitter and non-bitter fruit pulp. Journal of Scienceand Food Agriculture 2000; 80:1763-1766.

[5] ASEAN Manual of food analysis 2011. Regional Centre of ASEAN Network of Food Data System, Institute of Nutrition, Mahidol University, THAILAND.

[6] Chayanika Sahni, N. A. S. V. J. R. K. G., 2014. Screening of Nutritional, Phytochemical, Antioxidant and Antibacterial activity of the roots of Borassusflabellifer (Asian Palmyra Palm).. Journal of Pharmacognosy and Phytochemistry, 3(4), pp. 58-68.

[7] Jansz ER, Nikawela JK, Gooneratne J. Studies on thebitter principle and debittering of Palmyrah fruit pulp.Journal of Science and Food Agriculture 1994; 65:185-189.

[8] Nutrition a guide to Data Collection 2005, Analysis, Interpretation and Use Food Security Analysis Unit FSAU is managed by FAO for Somalia.

[9] AOAC, Official Methods of Analysis of the Association of Official Analytical Chemists, 16th ed., (Arlington, Virginia: AOAC International, 1995)

[10] G.I. Onwuka, Food Analysis and Instrumentation: Theory and Practice (Lagos: Naphthali Prints, 2005) 1-219.

[11] C.S. James, Analytical Chemistry of Foods (New York: Blackie Academic and Professional, 1996) 207-219.D.A. Pearson, The Chemical analysis of foods, 7th ed. (Edinburgh: Churchill Livingstone, 1976).

[12] AOAC. 2000. Official methods of analysis. (n.d.) Association of Analytical Chemists, 15th edition Virgina U.S.A 125139. ASEAN Manual of food analysis (2011) Regional Centre of ASEAN Network of Food Data System, Institute of Nutrition, Mahidol University, THAILAND.

[13] Chayanika Sahni, N. A. S. V. J. R. K. G., 2014. Screening of Nutritional, Phytochemical, Antioxidant and Antibacterial activity of the roots of Borassusflabellifer (Asian Palmyra Palm).. Journal of Pharmacognosy and Phytochemistry, 3(4), pp. $58-68$

[14] Second edition 2005A Guide to Data Collection, Analysis, Interpretation and UseFood Security Analysis Unit for Somalia (FSAU)

[15] Asmussen, C.B., Dransfield, J., Deickmann, V., Barfod, A.S., Pintaud, J.C. and Baker.W.J.2006. A new subfamily classification of the palm family (Arecaceae): evidence from plastid DNA phylogeny. Botanical Journal of the Linnean Society. 151(1):15-38

[16] Nesbitt, M.2005.The Cultural history of plants. Taylor \&Francis . 173.

[17] Morton, J.F. 1988.Notes on distribution, propagation, and products of Borassus palms (Arecaceae). Economic botany. 42(3): 420-441.

[18] Ghosh, S., Chakraborty, R. and Raychaudhuri, U. 2012. Optimizing process conditions for palm (Borassusflabelliffer) wine fermentation using Response Surface Methodology. International Food Research Journal. 19: 1633-1639.

[19] Nadkarni, K. M. 1954. Indian MateriaMedica, Popular Book Dept, Bombay, India .3(4): 2571-2575 Kapoor, L.D. 2000. Hand book of ayurvedicmedicinalplants:Herbal reference library press, p 82, USA, Florida

[20] Prof. K.Balasubramaniam, Prof. E.R.Jansz, Ms.Darshika D. Ariyasena (Palmyrah)

[21] Prof. K.Balasubramaniam, P. E. M. D. A., 1999. Palmyrah.

[22] E.R.Jansz, N. T. W. a. K. S., 2002. A review of the chemistry and biochemistry of seed shoot flour and fruit pulp of the palmyrah palm. Journal of science foundation sri lanka, 30(1\&2), pp. 61-87. 